\title{
In silico identification of potential chaperone genes that belong to type III and type IV secretion systems in Xanthomonas axonopodis pv citri
}

\author{
Letícia Khater ${ }^{1,2}$, Túlio M. Santos ${ }^{1}$, Marcos C. Alegria ${ }^{3}$, Cassia Docena ${ }^{3}$, Ana C.R. da Silva ${ }^{3}$ \\ and Carlos H.I. Ramos ${ }^{1,2}$ \\ ${ }^{1}$ Laboratório Nacional de Luz Síncrotron, Centro de Biologia Molecular Estrutural, \\ Campinas SP, Brazil. \\ ${ }^{2}$ Universidade Estadual de Campinas, Instituto de Biologia, Departamento de Bioquímica, \\ Campinas, SP, Brazil. \\ ${ }^{3}$ Universidade de São Paulo, Instituto de Química, Departamento de Bioquímica, \\ São Paulo, SP, Brazil.
}

\begin{abstract}
The secretion of bacterial virulence factors and flagellar components requires the assistance of specific type III and flagellar chaperones. Standard computational annotation of the genome of Xanthomonas axonopodis pv citri, a plant pathogen that causes citrus canker, initially did not identify any genes belonging to these chaperone categories since the primary sequence homology between them was very low. However, in a search for hypothetical proteins with characteristics similar to these chaperones, we have now identified 30 chromosomal and 10 plasmidial potential genes encoding chaperones belonging to types III/IV, and flagellar secretion systems in this organism. The significance of these findings is discussed.
\end{abstract}

Key words: chaperone, protein secretion, type III and type IV secretion systems, Xanthomonas.

Received: August 7, 2004; Accepted: December 8, 2004.

\section{Introduction}

Bacterial pathogens use the type III and type IV secretion systems to transfer virulence proteins to animal or plant cells (Wattiau et al., 1996; Winans et al., 1996; Hueck, 1998). Hence, these secretion systems are critical for bacterial pathogenicity and the initiation of disease (Gálan and Collmer, 1999; Cornelis and Van Gijsegem, 2000). The type III and type IV secretion systems require cell-to-cell contact and molecular chaperones for secretion (Deng et al., 1999), and are involved in the assembly of extracelullar filaments or pili (Christie, 1997). The flagellum-specific secretion pathway is considered to be the archetype of the type III secretion system in bacteria that interact with plants and animals, and is thus part of the type III superfamily. Thus, the proteins that form the type III apparatus are homologous to proteins that are essential for the assembly of surface flagella required for bacterial motility (Aizawa, 1996; Stephens and Shapiro, 1996; Hueck, 1998; Minamino and MacNab, 1999; MacNab,

Send correspondence to Carlos H.I. Ramos. Laboratório Nacional de Luz Síncrotron, Centro de Biologia Molecular Estrutural, Caixa Postal 6192, 13084-971 Campinas SP, Brazil. E-mail: cramos@ Inls.br.
2003). The type IV system resembles bacterial conjugation systems and is involved in host cell contact-mediated protein translocation (Covacci et al., 1999).

Although the details of the signaling pathway involved in delivery to the target are still uncertain (see, for instance, Anderson and Schneewind, 1997; Aldridge and Hughes, 2001; Lloyd et al., 2001), it is generally accepted that chaperone binding prevents non-productive pre-secretory associations with its substrates (Hueck, 1998; Wattiau and Cornelis, 1993). The main role suggested for type III chaperones is to maintain the bound proteins in a partially folded conformation, or secretion-competent state, that is able to engage the secretory machinery and travel through the secretory pathway (Woestyn et al., 1996; Bennett and Hughes, 2000; Stebbins and Gálan, 2001).

In general, chaperones of the effector class are responsible for only one secreted protein, the effector, whereas chaperones of the translocator class bind two related proteins (Cornelis and Van Gijsegem, 2000). To date, three classes of type III chaperones have been distinguished based on their target category (Page and Parsot, 2002). The SycE-like family (alpha-beta class) associates with only one effector protein, the $\mathrm{SycD} / \mathrm{LcrH}$ family associates with 
two translocator proteins, and members of the Spa 15 associates with several effector proteins (Page et al., 2002; Pallen et al., 2003 and references therein). The SycD/LcrH family is distinguished by a tetratricopeptide repeat (TPR) motif (Pallen et al., 2003), which is an imperfect 34 amino acid repeat often arranged in tandem arrays (Goebl and Yanagida, 1991).

The importance of secretion chaperones to bacteria is enormous since intact chaperones are required for substrate secretion (Wattiau et al., 1994; Iriarte and Cornelis, 1998) and may act as regulators of virulence gene expression (Lloyd et al., 2001). Thus, to understand the secretion systems of bacteria, the chaperones involved in each pathway need to be identified. Xanthomonas axonopodis pv citri is the causal agent of citrus canker, a serious but still poorly understood disease that affects most commercial citrus cultivars in more than 30 countries (for a recent review of Xanthomonas, see Brunings and Gabriel, 2003). This bacterium has the type III cluster present in its chromosome, and two type IV secretion systems, one present in the chromosome and the other in the plasmid pXAC64 (da Silva et al., 2002). Bonas and coworkers (Fenselau et al., 1992; Buttner and Bonas, 2002 and references therein) showed that certain Xanthomonas species use their type III system to inject virulence effector proteins into eukaryotic cells. The genome of Xanthomonas axonopodis pv citri has been fully sequenced (da Silva et al., 2002) and its initial annotation, based on DNA sequence homology, showed no type III chaperone genes. We have reanalyzed the genome of this bacterium using bioinformatic tools to search for hypothetical proteins with predominant type III and flagellar chaperone characteristics (see Bennett and Hughes, 2000 and others for discussion of these characteristics). The results of this analysis indicate the presence of secretion system chaperone genes in the genome of Xanthomonas axonopodis pv citri.

\section{Material and Methods}

\section{Prevalent structural characteristics of type III chaperones used to analyse the genome of Xanthomonas axonopodis pv citri}

The genes encoding particular type III chaperones are often located adjacent to the gene encoding their particular effector in the genome. Thus, the co-expression of these genes increases the performance of the system. Although primary sequence identity is low or not evident among type III and flagellar chaperones, these proteins share several features that can be used to classify them in their respective classes. Such features include a low molecular mass $(<20 \mathrm{kDa})$, a generally low isoelectric point, and a secondary structure predicted to be predominantly helical with a putative amphipathic $\alpha$-helix located at the $\mathrm{N}$ - or $\mathrm{C}$ terminus (for a discussion of these features see Wattiau et al., 1996; Gygi et al., 1997; Fraser et al., 1999; Bennett and
Hughes, 2000). The presence of such features in a hypothetical gene sequence provides the first indication of the function of the protein until more data become available.

\section{Homology search strategy}

To find potential type III and flagellar chaperone genes in Xanthomonas axonopodis pv citri, we used two independent strategies to search the genome of this pathogen (Figure 1). In the first round, a database containing sequences belonging to type III and flagellar chaperones from several species of bacteria was generated using the Entrez databank (http://www.ncbi.nlm.nih.gov/Entrez/). These sequences were aligned using the DIALIGN 2 (Morgenstern, 1999) and CLUSTAL W (Thompson et al., 1994) programs. This alignment allowed redundant sequences in the type III chaperones database to be discarded and decreased their number. BlastP software (Altschul et al., 1990) was then used to compare the generated database with the Xanthomonas axonopodis pv citri genome in order to find potential type III and flagellar chaperone genes. The default parameters used in this analysis included BLOSUM62 matrix, an e-value for inclusion in subsequent iterations of 0.005 , a word size of 3 , gap costs of existence 10 and extension 1, and no filter. The ANTHEPROT (ANalyse THE PROTeins; Deleage et al., 1988, 2001) and Compute pI/Mw (Bjellqvist et al., 1993, 1994) software packages,
First round

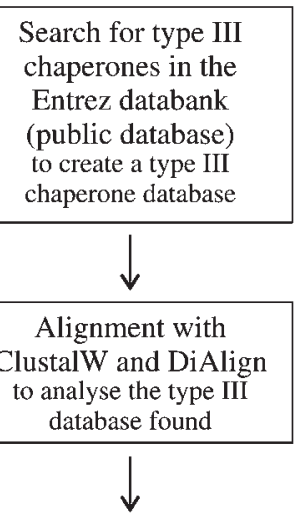

Analysis with ANTHEPROT and $\mathrm{pl} / \mathrm{Mw}$ programs:

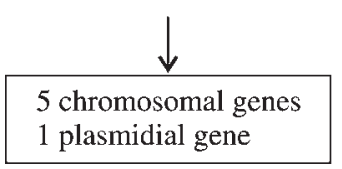

Second round

Search in the Xanthomonas ax. pv. citri database

for genes that encode hypothetical proteins close to pathogenicity and virulence genes

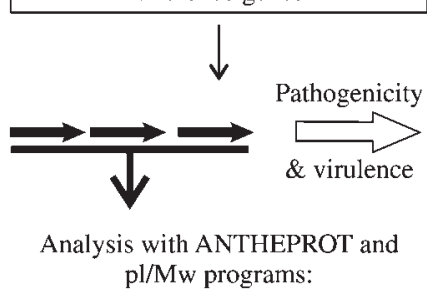

- $\mathrm{Mw}<20 \mathrm{kDa}$

- Low isoeletric point

- Secondary structure predominantly helical

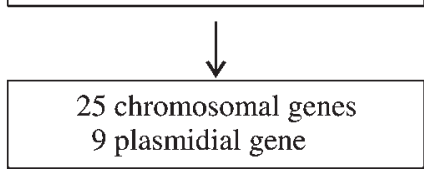

Figure 1 - Schematic representation of the two strategies used to search the Xanthomonas axonopodis pv citri genome for potential type III chaperone genes. The figure schematically represents the two strategies used to search the Xanthomonas axonopodis pv citri genome (da Silva et al., 2002) for potential type III chaperone genes. See Material and Methods for details and software references. 
which perform large scale protein sequence analyses to predict protein secondary structure and physico-chemical parameters, were used to determine whether the potential Xanthomonas axonopodis pv citri type III and flagellar chaperones genes found had the global type III chaperone characteristics described above. In the second round of analysis, the genes in the Xanthomonas axonopodis pv citri genome (da Silva et al., 2002) located within $1.5 \mathrm{~kb}$ of pathogenic and virulence clusters, were analysed individually with the ANTHEPROT and Compute $\mathrm{pI} / \mathrm{Mw}$ packages to identify potential physico-chemical characteristics similar to type III chaperones.

\section{PSI-BLAST search for conserved domains in secretion chaperones.}

A PSI-BLAST search (Altschul et al., 1997) was performed on the NCBI site (http://www.ncbi.nlm.nih.gov/ BLAST/) using the established default parameters (see above) in order to verify whether the genes selected have characteristic secretion chaperone domains, such as tetratricopeptide (TPR)-like repeats (Pallen et al., 2003), Spa15 family characteristic residues (Page et al., 2002), or similarity to the SycE family (Woestyn et al., 1996).

\section{Results}

The analysis for redundancy in the type III chaperone database generated from the Entrez databank reduced the number of sequences belonging to type III and flagellar system chaperones to 120 . The Xanthomonas axonopodis pv citri genome was searched for genes homologous to each of these 120 sequences. The other hypothetical genes close to pathogenic and virulence clusters in the Xanthomonas axonopodis pv citri genome were analyzed individually for potential physico-chemical characteristics similar to those of type III chaperones using the programs described in the Material and Methods section. The sequences selected by these two approaches were then ana- lyzed for their cellular location in order to eliminate sequences not predicted to be in the periplasm. Five of the putative secretion chaperone genes found in the first round were located on the chromosome and one in the plasmid pXAC33, and had type III and flagellar chaperone characteristics, as described in Material and Methods. This approach allowed the identification of proteins with $\geq 45 \%$ similarity to type III and flagellar chaperones of other bacteria (Table 1). The second approach selected 25 chromosomal genes and 9 plasmidial genes with secretion chaperones characteristics (Table 2). A total of 40 potential type III/IV or flagellar chaperone genes were identified in the Xanthomonas axonopodis pv citri genome, with 30 located on the chromosome and 10 located in the two plasmids, pXAC33 and pXAC64 (da Silva et al., 2002).

As an example of this approach, the analysis for two potential type III chaperones in Xanthomonas axonopodis pv citri is shown in Figure 2. This figure illustrates the amphipathic $\alpha$-helix wheel predicted from the primary amino acid sequences of the potential chaperones NP_640774 (Figure 2a) and NP_640641 (Figure 2b). The amphipathic $\alpha$-helix has predominantly nonpolar amino acid residues along one side and polar residues along the other. The presence of an amphipathic $\alpha$-helix is one of the characteristics of secretion chaperones.

\section{Discussion}

Secretory systems are of fundamental importance for several species of bacteria that use the systems to assemble the flagellum and to secrete important, mainly pathogenic factors, into the environment (Hueck, 1998; Gálan and Collmer, 1999; Cornelis and Van Gijsegem, 2000; $\mathrm{MacNab}, 2003)$. The acquisition of a type III secretory system allows many gram-negative bacteria to become pathogens since mutants with a disabled type III system are nonpathogenic (Hueck, 1998; Neyt and Cornelis, 1999).

Table 1 - Potential type III chaperone genes identified by sequence homology and predicted protein physico-chemical characteristics. The Xanthomonas axonopodis pv citri genome was searched for homology to type III chaperones. Five of the identified genes are localized in the chromosome and one in the plasmid pXAC33 (da Silva et al., 2002). All 6 were confirmed for type III chaperone characteristics as described in Material and Methods. This method allowed the identification of genes with $45 \%$ (or higher) homology to type III and flagellar chaperones.

\begin{tabular}{|c|c|c|c|c|c|c|}
\hline \multicolumn{5}{|c|}{ Putative secretion chaperone } & \multirow{3}{*}{$\begin{array}{l}\text { Protein homologue / } \\
\text { gene number }\end{array}$} & \multirow{3}{*}{$\mathrm{S}(\%)$} \\
\hline \multirow{2}{*}{$\begin{array}{l}\text { Xanthomonas } \\
\text { axonopodis pv citri } \\
\text { Gene ID }\end{array}$} & \multirow{2}{*}{$\begin{array}{c}\text { Genome } \\
\text { localization }\end{array}$} & \multicolumn{3}{|c|}{ Predicted physico-chemical parameters } & & \\
\hline & & MW (kDa) & $\mathrm{pI}$ & $\begin{array}{l}\text { Residues involved in the } \\
\text { Amphipathic domain }\end{array}$ & & \\
\hline NP_642798.1 & $\mathrm{C}$ & 17.8 & 5.8 & $98-111$ & FliS / gi2276420 & 49 \\
\hline NP_641681.1 & $\mathrm{C}$ & 10.9 & 5.6 & $88-100$ & FliJ / gi1518878 & 51 \\
\hline NP_642046.1 & $\mathrm{C}$ & 12.7 & 6.8 & $100-117$ & YscB / gi2635354 & 63 \\
\hline NP_643331.1 & $\mathrm{C}$ & 20.2 & 4.5 & $158-175$ & FliJ / gi1518878 & 45 \\
\hline NP_641682.1 & $\mathrm{C}$ & 17.1 & 5.5 & $92-102$ & FliJ / gi1518878 & 48 \\
\hline NP_644711.1 & $\mathrm{P}$ & 21.3 & 6.0 & $152-162$ & Spa15/gi13449095 & 56 \\
\hline
\end{tabular}

C, chromosomal gene; $\mathrm{P}$, plasmidial gene; $\mathrm{S}$, similarity. 
Table 2 - Potential type III chaperone genes determined by analysis of sequences localized near pathogenic and virulence clusters. Hypothetical genes in the Xanthomonas axonopodis pv citri genome (da Silva et al., 2002) localized near $(<1.5 \mathrm{~kb})$ pathogenic and virulence clusters, were individually analyzed with the programs described in the Material and Methods section for potential physico-chemical characteristics similar to type III chaperones. This method allowed the identification of 34 potential secretion system chaperone genes, 25 localized at the chromosome and 9 localized at the two plasmids, pXAC33 and pXAC64.

\begin{tabular}{|c|c|c|c|c|}
\hline \multicolumn{5}{|l|}{ Putative secretion chaperone } \\
\hline \multirow{2}{*}{$\begin{array}{l}\text { Xanthomonas axonopodis } \\
\text { pv citri Gene ID }\end{array}$} & \multirow{2}{*}{$\begin{array}{l}\text { Genome } \\
\text { localization }\end{array}$} & \multicolumn{3}{|c|}{ Predicted physico-chemical parameters } \\
\hline & & $\begin{array}{l}\text { MW } \\
(\mathrm{kDa})\end{array}$ & $\mathrm{pI}$ & $\begin{array}{l}\text { Residues involved in the } \\
\text { Amphipathic domain }\end{array}$ \\
\hline \multicolumn{5}{|l|}{ Near avirulence genes (avr) } \\
\hline NP_640641.1 & $\mathrm{C}$ & 18.6 & 7.0 & $69-97$ \\
\hline NP_643529.1 & $\mathrm{C}$ & 14.7 & 9.1 & $69-84$ \\
\hline NP_641699.1 & $\mathrm{C}$ & 16.3 & 5.5 & $72-83$ \\
\hline NP_643565.1 & $\mathrm{C}$ & 12.9 & 6.9 & $54-66$ \\
\hline NP_641577.1 & $\mathrm{C}$ & 18.1 & 6.9 & $61-76$ \\
\hline \multicolumn{5}{|c|}{ Near hypersensitivity response and pathogenicity genes (Type III cluster) } \\
\hline NP_641599.1 & $\mathrm{C}$ & 14.3 & 8.5 & $54-79$ \\
\hline NP_640774.1 & $\mathrm{C}$ & 10.7 & 7.0 & $67-91$ \\
\hline NP_642316.1 & $\mathrm{C}$ & 12.1 & 6.7 & $22-38$ \\
\hline \multicolumn{5}{|c|}{ Near host cell wall degradation genes } \\
\hline NP_640498.1 & $\mathrm{C}$ & 11.3 & 10.3 & $1-18$ \\
\hline NP_640495.1 & $\mathrm{C}$ & 17.1 & 6.2 & $16-30$ \\
\hline NP_640494.1 & $\mathrm{C}$ & 18.6 & 7.7 & $147-165$ \\
\hline NP_640523.1 & $\mathrm{C}$ & 14.0 & 11.3 & $36-52$ \\
\hline NP_643871.1 & $\mathrm{C}$ & 16.6 & 10.8 & $80-96$ \\
\hline NP_643873.1 & $\mathrm{C}$ & 12.3 & 7.7 & $100-114$ \\
\hline NP_640383.1 & $\mathrm{C}$ & 15.7 & 5.62 & $21-36$ \\
\hline NP_643815.1 & $\mathrm{C}$ & 13.3 & 11.3 & $1-14$ \\
\hline NP_642683.1 & $\mathrm{C}$ & 10.5 & 4.5 & $61-77$ \\
\hline \multicolumn{5}{|c|}{ In the type IV secretion system cluster } \\
\hline NP_641701.1 & $\mathrm{C}$ & 22.6 & 6.2 & $148-165$ \\
\hline NP_642723.1 & $\mathrm{C}$ & 17.8 & 5.2 & $42-58$ \\
\hline NP_642935.1 & $\mathrm{C}$ & 14.7 & 6.0 & $55-71$ \\
\hline NP_640924.1 & $\mathrm{C}$ & 15.4 & 4.7 & $42-60$ \\
\hline NP_642924.1 & $\mathrm{C}$ & 17.1 & 8.1 & $71-84$ \\
\hline NP_642919.1 & $\mathrm{C}$ & 17.2 & 8.4 & $53-65$ \\
\hline NP_644761.1 & $\mathrm{P}$ & 8.4 & 5.6 & $01-13$ \\
\hline NP_644763.1 & $\mathrm{P}$ & 15.8 & 7.9 & $110-122$ \\
\hline NP_644770.1 & $\mathrm{P}$ & 14.2 & 9.8 & $123-129$ \\
\hline NP_644771.1 & $\mathrm{P}$ & 9.4 & 9.1 & $28-41$ \\
\hline NP_644776.1 & $\mathrm{P}$ & 13.9 & 8.6 & $87-97$ \\
\hline NP_644777.1 & $\mathrm{P}$ & 13.6 & 8.5 & $71-82$ \\
\hline \multicolumn{5}{|l|}{ Nearby virB6 protein } \\
\hline NP_642918.1 & $\mathrm{C}$ & 16.6 & 5.5 & $126-142$ \\
\hline NP_642914.1 & $\mathrm{C}$ & 16.4 & 10.2 & $95-108$ \\
\hline \multicolumn{5}{|c|}{ Near pathogenicity, virulence and adaptation genes } \\
\hline NP_644726.1 & $\mathrm{P}$ & 16.1 & 10.9 & $96-110$ \\
\hline NP_644791.1 & $\mathrm{P}$ & 17.2 & 12.1 & $5-21$ \\
\hline NP_644792.1 & $\mathrm{P}$ & 16.2 & 11.7 & $110-126$ \\
\hline
\end{tabular}

C. chromosomal gene; P. plasmidial gene. 

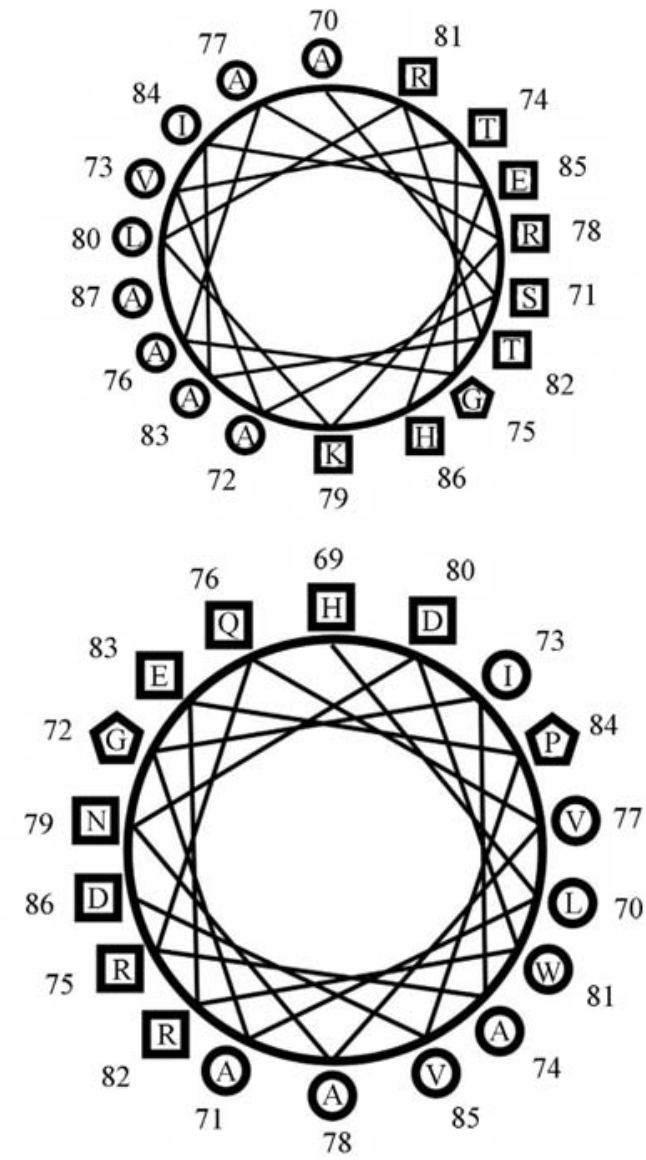

0

Hidrophobic

0 Others

$\square$ Hydrophilic

Figure 2 - Predicted amphiphatic $\alpha$-helical wheel of potential secretion chaperone. The genes NP_640774 (a) and NP_640641 (b) were selected as potential secretion chaperones because they were located near pathogenic and virulence clusters and because they had predicted protein physico-chemical characteristics similar to those of type III chaperones (see Table 2). Analysis with the ANTHEPROT software package (ANalyse THE PROTeins; Deleage et al., 1988; Deleage et al., 2001) allowed the prediction of a potential amphipathic $\alpha$-helical wheel at the protein $\mathrm{C}$-terminus. Amphipatic $\alpha$-helices have predominantly nonpolar amino acid residues along one side and polar residues along the other side.

Type III secretory systems have been found in animal and plant pathogens, and show varying degrees of homology, from highly conserved (some proteins of the secretory apparatus) to quite divergent (chaperones and translocators) or very diverse (effectors) (Bennett and Hughes, 2000; Subtil et al., 2000). The secreted proteins must be targeted to the secretory apparatus in order to be secreted. One of the most important mechanisms for labeling and delivering the proteins to be secreted involves chaperones that recognize the target proteins and direct them to the secretory apparatus (Wattiau and Cornelis, 1993; Hueck, 1998; Bennett and Hughes, 2000; Stebbeins and Gálan, 2001). Curiously, no type III chaperone genes were annotated in the fully sequenced genome of Xanthomonas axonopodis pv citri (da Silva et al., 2002).
Large-scale DNA sequencing efforts produce a huge amount of data that require detailed analysis to be well understood. The analysis of sequences and their annotation by homology is a suitable method to identify potential proteins in a sequenced genome. Since standard techniques did not annotate type III and type IV chaperones in the Xanthomonas axonopodis pv citri genome, we undertook a more specific analysis of this genome to search for these chaperones. For this, we used homology to search for specific sequences followed by a search for potential physico-chemical properties of the proteins. Several hypothetical genes in the Xanthomonas axonopodis pv citri genome were analyzed in order to identify those belonging to the secretion chaperone categories. These approaches have been used to show the presence of proteins in certain organisms (see for instance Lawson, 1999; Subtil et al., 2000; Searls, 2000; and others). The comparison of multiple sequences can reveal gene functions that are not detected by simple sequence homology searches.

Secretion system chaperones vary in their amino acid sequences, but share a few common properties, including genome localization close to the gene encoding the target protein, a low isoelectric point, a low molecular weight, and a putative amphiphathic alpha-helix at the $\mathrm{N}$ - or C-terminus (Bennett and Hughes, 2000; Parsot et al., 2003). Our analyses of the Xanthomonas axonopodis pv citri genome using the tools described here allowed the identification of 40 potential secretion system chaperone genes, 30 which were located on the chromosome and 10 in the two plasmids. The first round of the search for potential type III chaperones identified several hypothetical genes that shared similarity with type III chaperones from other bacteria. Two potential chaperones with similarity to the chaperone families SycE and Spa15 were found. The Xanthomonas axonopodis pv citri gene NP 642046.1 was similar to the secretion chaperone $\mathrm{YscB}$ that belongs to the SycE family and functions as a chaperone for the protein YopN in Yersinia pestis (Day and Plano 1998). Xanthomonas axonopodis pv citri gene NP_644711.1 was similar to the secretion chaperone Spa15 from Shigella flexneri and also to InvB from other bacteria that belong to a third class of chaperones in the type III secretion pathway (Page et al., 2002). The potential chaperones identified here did not have the TPR domain characteristic of the SycD family (Pallen et al., 2003). Genes belonging to the flagellum assembly apparatus were also identified in Xanthomonas axonopodis pv citri. Several of these sequences showed homology with FliJ from Rhodobacter sphaeroides and FliS from Pseudomonas aeruginosa. FliJ is a general flagellar chaperone related to the export process itself and FliS plays a role in protecting the target proteins before exportation (Minamino et al., 2000).

Our results also indicated the presence of potential chaperone genes that may belong to the type IV secretion system because most of the genes identified in the second 
round of searching were located close to the type IV system cluster. However, this characteristic may not be enough to support this conclusion and since some type IV chaperones share most of the type III chaperone characteristics (for instance VirE1; Deng et al., 1999) we can only state that the annotated chaperones are related to type III/IV systems.

Type III secretion system occurs in other Xanthomonas species (Fenselau et al., 1992; Buttner and Bonas, 2002) and our results indicated the presence of chaperones belonging to this system, and to the flagellar and type IV systems in Xanthomonas axonopodis pv citri. Together, the results presented here are important for understanding the pathogenicity of Xanthomonas axonopodis pv citri and may be useful in studies of the mechanism of disease caused by this pathogen in orange plantations. To date, few reports have described a requirement for chaperones in the type III secretion systems of plant pathogens (see for instance, Gaudriault et al., 1997; van Dijk et al., 2002). In conclusion, the study of Xanthomonas axonopodis will benefit from the identification of secretion system chaperone genes since uncovering the precise molecular events controlling the delivery of effector proteins should eventually allow the design of compounds that specifically interfere with these processes, hopefully without deleterious side effects to the host plant (Staskawicz, 2001).

\section{Acknowledgments}

This work was supported by Fundação de Amparo à Pesquisa do Estado de São Paulo (FAPESP) and Conselho Nacional de Desenvolvimento Científico e Tecnológico (CNPq). LK, TMS, MCA, and CD were supported by fellowship from FAPESP.

\section{References}

Aizawa SI (1996) Flagellar assembly in Salmonella typhimurium. Mol Microbiol 19:1-5.

Aldridge P and Hughes KT (2001) How and when are substrates selected for type III secretion? Trends Microbiol 9:209-214.

Altschul SF, Gish W, Miller W, Myers EW and Lipman DJ (1990) Basic local alignment search tool. J Mol Biol 215:403-410.

Altschul SF, Madden TL, Schaffer AA, Zhang J, Zhang Z, Miller W and Lipman DJ (1997) Gapped BLAST and PSI-BLAST: A new generation of protein database search programs. Nucleic Acids Res 25:3389-3402.

Anderson DM and Schneewind O (1997) A mRNA signal for the type III secretion of Yop proteins by Yersinia enterocolytica. Science 278:1140-1143.

Bennett JCQ and Hughes C (2000) From flagellum assembly to virulence. Trends Microbiol 8:202-204.

Bjellqvist B, Basse B, Olsen E and Celis JE (1994) Reference points for comparisons of two-dimensional maps of proteins from different human cell types defined in a $\mathrm{pH}$ scale where isoelectric points correlate with polypeptide compositions. Electrophoresis 15:529-539.
Bjellqvist B, Hughes GJ, Pasquali C, Paquet N, Ravier F, Sanchez J-C, Frutiger S and Hochstrasser DF (1993) The focusing positions of polypeptides in immobilized $\mathrm{pH}$ gradients can be predicted from their amino acid sequences. Electrophoresis 14:1023-1031.

Blasco F, Dos Santos JP, Magalon A, Frixon C, Guigliarelli B, Santini CL and Giordano G (1998) NarJ is a specific chaperone required for molybdenum cofactor assembly in nitrate reductase A of Escherichia coli. Mol Microbiol 28:435-447.

Brunings AM and Gabriel DW (2003) Xanthomonas citri: Breaking the surface. Mol Plant Pathol 4:41-57.

Buttner D and Bonas U (2002) Getting across-bacterial type III effector proteins on their way to the plant cell. EMBO J 21:5313-5322.

Christie PJ (1997) Agrobacterium tumefaciens T-complex transport apparatus: A paradigm for a new family of multifunctional transporters in eubacteria. J Bacteriol 179:3085-3094.

Cornelis GR and Van Gijsegem F (2000) Assembly and function of type III secretory systems. Annu RevMicrobiol 54:735774.

Cornelis GR and Wolf-Watz H (1997) The Yersinia Yop virulon: A bacterial system for subverting eukaryotic cells. Mol Microbiol 23:861-867.

Covacci A, Telford JL, Del Giudice G, Parsonnet J and Rappuoli R (1999) Helicobacter pylori virulence and genetic geography. Science 284:1328-1333.

da Silva ACR, Ferro JA, Reinach FC, Farah CS, Furlan LR, Quaggio RB, Monteiro-Vitorello CB, Van Sluys MA, Almeida NF, Alves LM, do Amaral AM, Bertolini MC, Camargo LE, Camarotte G, Cannavan F, Cardozo J, Chambergo F, Ciapina LP, Cicarelli RM, Coutinho LL, Cursino-Santos JR, El-Dorry H, Faria JB, Ferreira AJ, Ferreira RC, Ferro MI, Formighieri EF, Franco MC, Greggio CC, Gruber A, Katsuyama AM, Kishi LT, Leite RP, Lemos EG, Lemos MV, Locali EC, Machado MA, Madeira AM, Martinez-Rossi NM, Martins EC, Meidanis J, Menck CF, Miyaki CY, Moon DH, Moreira LM, Novo MT, Okura VK, Oliveira MC, Oliveira VR, Pereira HA, Rossi A, Sena JA, Silva C, de Souza RF, Spinola LA, Takita MA, Tamura RE, Teixeira EC, Tezza RI, Trindade dos Santos M, Truffi D, Tsai SM, White FF, Setubal JC and Kitajima JP (2002) Comparison of the genomes of two Xanthomonas pathogens with differing host specificity. Nature 417:459-463.

Day JB and Plano GV (1998) A complex composed of SycN and YscB functions as a specific chaperone for YopN in Yersinia pestis. Mol Microbiol 30:777-788.

Deleage G, Clerc FF, Roux B and Gautheron DC (1988) ANTHEPROT: A package for protein sequence analysis using a microcomputer. Comput Appl Biosci 4:351-356.

Deleage G, Combet C, Blanchet C and Geourjon C (2001) ANTHEPROT: An integrated protein sequence analysis software with client/server capabilities. Comput Biol Med 31:259-267.

Deng W, Chen L, Peng WT, Liang X, Sekiguchi S, Gordon MP, Comai L and Nester EW (1999) VirE1 is a specific molecular chaperone for the exported single-stranded-DNAbinding protein VirE2 in Agrobacterium. Mol Microbiol 31:1795-1807.

Fenselau S, Balbo I and Bonas U (1992) Determinants of pathogenicity in Xanthomonas campestris pv vesicatoria are related 
to proteins involved in secretion in bacterial pathogens of animals. Mol Plant Microbe Interact 5:390-396.

Fraser GM, Bennett JCQ and Hughes C (1999) Substrate-specific binding of hook-associated proteins by FlgN and FliT, putative chaperones for flagellum assembly. Mol Microbiol 32:569-580.

Gálan JE and Collmer A (1999) Type III secretion machines: Bacterial devices for protein delivery into host cells. Science 284:1322-1328.

Gaudriault S, Malandrin L, Paulin JP and Barny, MA (1997) DspA, an essential pathogenicity factor of Erwinia amylovora showing homology with AvrE of Pseudomonas syringae, is secreted via the Hrp secretion pathway in a DspB-dependent way. Mol Microbiol 26:1057-1069.

Gygi D, Fraser, G, Dufour A and Hughes C (1997) A motile but non-swarming mutant of Proteus mirabilis lacks FlgN, a facilitator of FliC export and flagella assembly. Mol Microbiol 25:597-604.

Goebl M and Yanagida M (1991) The TPR snap helix: A novel protein repeat motif from mitosis to transcription. Trends Biochem Sci 16:173-177.

Hueck CJ (1998) Type III protein secretion systems in bacterial pathogens of animals and plants. Microbiol Mol Biol Rev $62: 379-433$

Iriarte M and Cornelis GR (1998) YopT, a new Yersinia Yop effector protein, affects the cytoskeleton of host cells. Mol Microbiol 29:915-929.

Lawson D (1999) Data mining parasite genomes: Haystack searching with a computer. Parasitology 118:S15-S18.

Lloyd SA, Forsberg A, Wolf-Watz H and Francis MS (2001) Targeting exported substrates to the Yersinia TTSS: Different functions for different signals? Trends Microbiol 9:367-371.

MacNab RM (2003) How bacteria assemble flagella. Annu Rev Microbiol 57:77-100.

Minamino T, Chu R, Yamaguchi S and Macnab RM (2000) Role of FliJ in Salmonella J Bacteriol 182:4207-4215.

Minamino T and Macnab RM (1999) Components of the Salmonella flagellar export apparatus and classification of export substrates. J Bacteriol 181:1388-1394.

Morgenstern B (1999) DIALIGN 2: Improvement of the segment-to-segment approach to multiple sequence alignment. Bioinformatics 15:211-218.

Nakai K and Kanehisa M (1991) Expert system for predicting protein localization sites in Gram-negative bacteria. Proteins 11:95-110.

Neyt C and Cornelis GR (1999) Insertion of a Yop translocation pore into the macrophage plasma membrane by Yersinia enterocolitica: Requirement for translocators YopB and YopD, but not LcrG. Mol Microbiol 33:971-981.
Page A-L, Sansonetti P and Parsot C (2002) Spa15 of Shigella flexneri, a third type of chaperone in the type III secretion pathway. Mol Microbiol 43:1533-1542.

Page A-L and Parsot C (2002) Chaperones of the type III secretion pathway: Jacks of all trades. Mol Microbiol 46:1-11.

Pallen MJ, Francis MS and Fütterer K (2003) Tetratricopeptide-like repeats in type-III secretion chaperones and regulators. FEMS Microbiol Lett 223:53-60.

Parsot C, Hamiaux C and Page A-L (2003) The various and varying roles of specific chaperones in type III secretion systems. Curr Opin Microbiol 6:7-14.

Searls DB (2000) Using bioinformatics in gene and drug discovery Drug Discov Today 5:135-143.

Staskawicz BJ, Mudgett MB, Dangl JL and Galan JE (2001) Common and contrasting themes of plant and animal diseases. Science 22:2285-2289.

Stebbins CE and Galán JE (2001) Maintenance of an unfolded polypeptide by a cognate chaperone in bacterial type III secretion. Nature 414:77-81.

Stephens C and Shapiro L (1996) Bacterial pathogenesis: Delivering the payload. Curr Biol 6:927-930.

Subtil A, Blocker A, and Dautry-Varsat A (2000) Type III secretion system in Chlamydia species: Identified members and candidates. Microbes and Infection 2:367-369.

Thompson JD, Higgins DG and Gibson TJ (1994) CLUSTAL W: Improving the sensitivity of progressive multiple sequence alignment through sequence weighting, positions-specific gap penalties and weight matrix choice. Nucleic Acids Research 22:4673-4680.

van Dijk K, Tam VC, Records AR, Petnicki-Ocwieja T and Alfano JR (2002). The ShcA protein is a molecular chaperone that assists in the secretion of the HopPsyA effector from the type III (Hrp) protein secretion system of Pseudomonas syringae. Mol Microbiol 44:1469-81.

Wattiau P and Cornelis GR (1993) SycE, a chaperone-like protein of Yersinia enterocolitica involved in the secretion of YopE. Mol Microbiol 8:123-131.

Wattiau P, Bernier B, Deslée P, Michiels T and Cornelis GR (1994) Individual chaperones required for Yop secretion by Yersinia. Proc Natl Acad Sci USA 91:10493-10497.

Wattiau P, Woestyn S and Cornelis GR (1996) Customized secretion chaperones in pathogenic bacteria. Mol Microbiol 20:255-262.

Winans SC, Burns DL and Christie PJ (1996) Adaptation of a conjugal transfer system for the export of pathogenic macromolecules. Trends Microbiol 4:64-68.

Woestyn S, Sory MP, Boland A, Lequenne O and Cornelis GR (1996). The cytosolic $\mathrm{SycE}$ and $\mathrm{SycH}$ chaperones of Yersinia protect the region of YopE and YopH involved in translocation across eukaryotic cell membranes. Mol Microbiol 20:1261-1271.

Associate Editor: Sérgio Olavo Pinto da Costa 